\title{
WET AND DRY FEEDING OF CONCENTRATES TO DAIRY COWS.
}

\author{
Bx REGINALD ARTHUR BERRY, F.I.C. \\ (Professor of Agricultural Chemistry, West of Scotland College \\ of Agriculture, Glasgow.)
}

INTRODUCTION.

IN the winter feeding of cows in milk there is a diversity of opinion among dairy farmers as to the extent to which it is desirable to "prepare" the food. Some believe in expending no labour which can be avoided in the preparation of the food; the roots are fed whole, the hay and straw are used in their natural state, and the cakes and meals are given dry. Others slice or pulp the roots, and the concentrates are fed as wet mashes. In some cases the cales and meals in a sloppy condition are mixed with chaffed fodder and sliced roots, and distillery by-products such as draff are added to impart flavour as well as to furnish nutritive material. The mixture (chopp), which is sometimes further moistened with water, is left over-night to allow of a certain amount of fermentation, which is carried on at the expense principally of the digestible substances, to set in, the object being to make the food more appetising.

For the same reason steaming is sometimes resorted to. Steaming and cooking lower the digestibility of the proteins ${ }^{1}$ and render inactive the vitamine element ${ }^{2}$ of the food. Nevertheless to pigs foods such as potatoes are more suitable for feeding in the cooked compared with the raw state ${ }^{3}$. The softening of the food which results would be an advantage to ruminants when the material is so hard that it might otherwise escape mastication and digestion, but in that case it would perhaps be better to deal with it by grinding.

Cooking effectively destroys all forms of bacterial and fungoid growth, a result which would prove of use in the case of damaged and partly decomposed foods, but normal foods are rarely if ever benefited on this

1 Warrington, R. Chemistry of the Farm. Vinton \& Co., London, 1909, p. 150.

2 Report upon present state of knowledge concerning accessory food factors (Vitamines). Medical Research Committee, H.M.S. Printing Office, 1919, chap. IV, pp. 49-67.

3 Kellner, O. Scientific fecding of Animals. Duckworth \& Co., 1909, p. 179. 
account ${ }^{1}$. Steeping in cold or tepid water softens the food without diminishing its digestibility, unless the food contains nutritive substances soluble in water and the steep water is thrown away, then it would be lowered. Poisonous compounds soluble in water can be removed from foods by this means.

A method followed on many dairy farms in the south and southwestern counties of Scotland, is to mix the meals over night with hot or boiling water. The following morning sufficient hot water is added to raise the temperature to body heat and the whole is fed in a sloppy condition. It is claimed that the cows respond in milk better to the feeding of the meals "wet" compared with that from the same meals fed "dry."

Preparation or unnecessary handling of food increases the cost of feeding and consequently that of milk production, and unless an equivalent return is obtained the labour and expenditure involved could not be justified. For this reason it was decided to investigate the merits of the practice of feeding concentrates to dairy cows, (1) dry, and (2) scalded and given in a sloppy condition at body temperature; the effects on the yield of milk and on the health of the animal were to be taken as the principal bases for comparison.

It was anticipated that the difference likely to be obtained as a result of the feeding by the two methods would not be large and might come within the limits of the experimental error. As not more than ten cows were likely to be available at one time, at the College experimental station at Kilmarnock, grouping the cows into two balanced lots according to: period of lactation, milk yield, age of cow, date of service, etc., then feeding one lot on the dry and the other on the wet food, and taking the difference in the milk yield as being due to the difference in the feeding, was a method which could not be adopted. Unless a large number of cows were employed the experimental error would in all probability be greater than the difference it was sought to measure. The nature and the extent of the experimental errors, which are associated with investigations on milk production, were brought home to the author when carrying out an investigation on the summer feeding of cows on pasture, in which fifteen lots totalling 224 cows were employed ${ }^{2}$.

1 Cyclopedia of American Agriculture. Macmillan \& Co., 3, 1903.

2 Berry, R. A. "Feeding of dairy cows on pasture." W. of Scot. Agr. Coll., Glasgow, 1916. Bull. 76. 


\section{Wet and Dry Feeding of Concentrates to Dairy Cows}

\section{Plan of Experiment.}

Six animals calving within 35 days of each other were available in the autumn of 1913 , and they were separated into two groups. The plan adopted for the feeding was to divide the experiment into four equal periods. In the first period the animals in group 1 received the concentrates wet and alternately dry and wet in the following periods, while the animals in group 2 were fed in the reverse order, that is starting with the dry meal in the first period. The object of this arrangement was to bring out the effect, if any, of an advancing lactation and of varying weather conditions on the two methods of feeding. The allowance of roots, fodder, etc. was the same throughout.

The morning and evening milk respectively of each cow were weighed daily and the millk fat determined in each. A daily record was kept of the rainfall, humidity and maximum and minimum temperatures of the outside air. Other circumstances which might influence the result such as indisposition, change of milkers, etc., were recorded. At the commencement, sufficient fodder, roots and concentrates to cover the whole experiment were laid aside.

Daily ration for each cow.

\begin{tabular}{lllrr} 
& & & \multicolumn{2}{r}{ lbs. } \\
Swedes & $\ldots$ & $\ldots$ & $\ldots$ & 30 \\
Hay ... & $\ldots$ & $\ldots$ & $\ldots$ & 7 \\
Oat straw & $\ldots$ & $\ldots$ & $\ldots$ & 10 \\
Bean meal & $\ldots$ & $\ldots$ & $\ldots$ & 3 \\
Crushed oats & $\ldots$ & $\ldots$ & 3 \\
Decorticated cotton cake & $\ldots$ & 3
\end{tabular}

This supplied in lbs. : dry matter $25 \cdot 8$; dig. protein 2.2; dig. oil 0.62 . Dig. carbohydrates and fibre $12 \cdot 6$.

5.0 a.m. Milking.

\section{Daily programme.}

6.0 a.m. Concentrates 4 lbs. fed wet or dry. Straw ad lib. about 5 lbs.

8.15 a.m. Turnips sliced 15 lbs.

10-10.30 a.m. Cows put out to drink.

11.0 a.m. Hay $7 \mathrm{lbs}$.

3.0 p.m Turnips sliced 15 lbs.

4.0 p.m. Milking.

5.0 p.m. Concentrates $4 \frac{1}{2}$ lbs. fed wet or dry. Straw ad lib. about 5 lbs.

Method of feeding concentrates. 1. Wet. Equal weights of bean meal, crushed oats, and decorticated cotton cake were mixed and scalded at 3 p.m. at the rate of $\frac{1}{2}$ gallon boiling water to $9 \mathrm{lbs}$. of mixed meals to 
which was added $1 \mathrm{oz}$. of rock salt. In the following morning one half of the daily allowance was warmed to body temperature by adding $\frac{1}{4}$ gallon of hot water and fed to the animal, and in the afternoon the remaining half of the meal was warmed and fed in the same way. The meal for each animal was weighed out daily into a numbered bucket.

2. Dry. The mixed meals were fed in their natural state, one half of the daily allowance ( $4 \frac{1}{2} \mathrm{lbs}$.) being given in the morning and the remainder in the evening.

Nutted decorticated cotton cake was used for the dry feeding and the same ground to a meal for the wet feeding. The nutting and mealing of the cake was done locally.

A preliminary trial lasting three weeks preceded the actual experiment and in which one half of the meals were fed "dry" in the morning and the remainder "wet" in the evening.

\section{Effect of Short Periods of Feeding.}

Each period was of five weeks' duration. 'The average daily yield of milk in lbs. obtained for the feeding of the meals wet and dry respectively was as follows:

$\begin{array}{ccccc} & \text { Wet } & \text { Dry } & \text { Wet } & \text { Dry } \\ \text { Group 1. } & 24 \cdot 8 & 24 \cdot 1 & 24 \cdot 8 & 20 \cdot 0 \\ & \text { Dry } & \text { Wet } & \text { Dry } & \text { Wet } \\ \text { Group 2. } & 22 \cdot 1 & 23.5 & 24 \cdot 1 & 20.9\end{array}$

A comparison of the first three periods shows that the wet meal produced an a verage daily increase amounting to about $\frac{3}{4} \mathrm{lb}$. of milk per cow per day, over that produced by the dry meal. With the feeding in the reverse order (group.2) the result obtained also showed an advantage, though not so definite, in favour of the wet meal. In the last period the fall in the milk yield as a result of an advancing lactation, was less when . the cows received the wet compared with the dry meal (group 1).

A similar result was obtained in a ten week experiment carried out in the spring of the same year, when eight animals calving within 41 days of each other were employed. The experiment was divided into two periods of five weeks each. The average figures obtained in lbs. of milk were:

$\begin{array}{ccc} & \text { Wet } & \text { Dry } \\ \text { Group 1. } & 29 \cdot 3 & 23 \cdot 4 \\ & \text { Dry } & \text { Wet } \\ \text { Group 2. } & 29 \cdot 0 & 25 \cdot 4\end{array}$




\section{Wet and Dry Feeding of Concentrates to Dairy Cows}

In Fig. 1 below, the average daily yield of milk in lbs. per week for the cows in each group, the weekly rainfall in inches, the mean weekly temperature (average daily readings of maximum and minimum thermometers) and the humidity of the atmosphere (the daily differences between the readings of the wet and dry bulb thermometers) are represented in the form of curves.

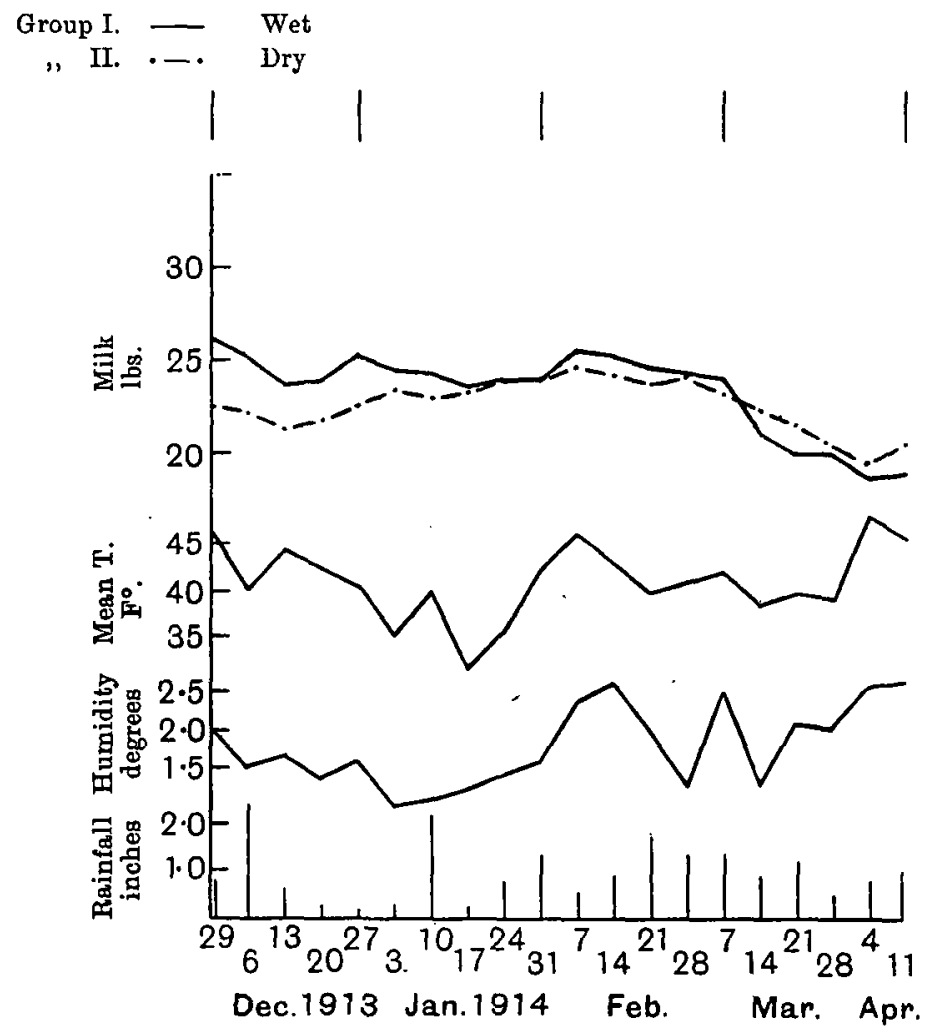

Fig. 1.

When examining the curves as well as the figures given (p. 81), it must be kept in mind that generally from about the fourth to the sixth week after calving, the curve for a normal milk yield would show a slow but continuous fall to the end of the lactation, and there would be a gradual rise in the percentage of milk fat. Further the effect of the feeding in one period may extend into that of the succeeding period. It is a well established fact that liberal supplies of suitable food stimulate the process of mill secretion, thus with a change from a limited to an ample supply of food, there is, as a rule, either a rise in the yield of milk, 
or the yield may remain stationary, and the fall due to an advancing lactation temporarily arrested. Moreover, it is a matter of common experience that a change of food or of environment is generally reflected in the yield of milk. Then there is the question of the existence of galactagogues ${ }^{1}$ and their effect on milk secretion, besides other factors which do not arise at this point, which go to make up the complicated and yet obscure process of milk formation.

A feature at once noticeable in the above graphs is the similarity in the form which the two milk curves take. Also there is the indication, more clearly shown in (curve) group 1, that a change in the method of feeding irrespective of whether it is to the wet or to the dry meals affects the milk yield, a result already shown in the figures given. It is plain, however, that the irregular form taken by the two curves is not the result of the feeding only. Whether the variable air temperature has had any influence on the milk yield is not clear from the graphs but the point is worth keeping in view (see p. 95).

As a rule the cows did not take quite as readily to the change from the wet to the dry as from the dry to the wet feeding. If in the first day of the change, any meal was left untouched in the trough, it was consumed in the following day.

\section{Efrects of Long Periods of Feeding.}

A ten week instead of a five week period for the wet and dry feeding respectively was tried. It was thought that any effect produced would more likely be brought out by prolonging the periods. In other respects the details of the experiment were the same. Daily observations such as the health, appetite, etc. of the cows, the weather conditions, and any other circumstances which it was thought might influence the result, were recorded.

\begin{tabular}{lllll} 
Daily rution for each cow. & \multicolumn{3}{c}{ lbs. } \\
& \multicolumn{4}{c}{ for } \\
Turnips & $\ldots$ & $\ldots$ & $\ldots$ & 30 \\
Hay $\ldots$ & $\ldots$ & $\ldots$ & $\ldots$ & 7 \\
Oat straw & $\ldots$ & $\ldots$ & $\ldots$ & 10 \\
Bean meal & $\ldots$ & $\ldots$ & $\ldots$ & $3 \frac{1}{2}$ \\
Crushed oats & $\ldots$ & $\ldots$ & $3 \frac{3}{2}$ \\
Decorticated cotton cake & $\ldots$ & 2
\end{tabular}

1 McCandlish, A. C. "Possibilities of increasing milk and butter fat production by the administration of Drugs." Jour. Dairy Sc., 1, No. 6, 1918, 475-486. Gavin, W. Quarl. Jour. Exper. Physiol., 1913. Hammond, J. and Hawk, J. C. "Studies in milk secretion." This Journ., 8, Pt. 2, 1917, 139-153. Hays, F. A. and Thomas, M. G. "Effects of drugs on milk and fat production." Jour. Agr. Research (U.S.), 3, 1920, pp. 123-130. 


\section{Wet and Dry Feeding of Concentrates to Dairy Cows}

This supplied in lbs. : dry matter 27.3 ; dig. protein 2.45 ; dig. oil 0.51 ; dig. carbohydrates and fibre, $13 \cdot 37$.

Ten animals calving within 45 days of each other were available. They were divided into two groups and the feeding of the concentrates was as follows:

$\begin{array}{rcc} & \text { Group 1 } & \text { Group 2 } \\ 5 \text { weeks } & \text { Dry } & \text { Wet } \\ 10 " & \text { Wet } & \text { Dry } \\ 2 " & \text { Dry } & \text { Wet }\end{array}$

Influence on the milk yield. The result of the feeding on the milk yield is shown in the average daily yield in lbs. given below:

$\begin{array}{cccc} & \text { Dry } & \text { Wet } & \text { Dry } \\ \text { Group 1. } & 29 \cdot 0 & 26 \cdot 2 & 24 \cdot 0 \\ & \text { Wet } & \text { Dry } & \text { Wet } \\ \text { Group 2. } & 28 \cdot 4 & 24 \cdot 4 & 23 \cdot 0\end{array}$

Owing to the periods not being of equal length the average yield of milk in one period is not comparable with that of another, but a comparison of the milk yield for group 1 can be made with that for group 2 . This comparison shows that the advantage in favour of feeding the wet meal is equal to an increase of more than $1 \mathrm{lb}$. of milk per head per day over that produced by the dry meal. The advantage diminishes as the lactation advances.

The effect of the feeding on the milk yield is shown graphically in Fig. 2, p. 85, along with curves giving the mean temperature and the average weekly rainfall.

After a long period of feeding with the dry meal a change to the wet meal is marked by a perceptible rise in the yield of milk, whilst with a change from the wet to the dry the yield remained stationary for a time.

The milk yield curves are more regular than those given in Fig. 1, p. 82. The temperature is also not so variable.

Other effects besides that on the milk yield produced by the feeding, were observed during the progress of the experiment, and were brought out as a result of extending the length of the period of feeding. They are given below.

Influence on the dung. The dung from the wet fed animals was loose and there was a tendency on the part of the animals to scour, whilst from the dry fed lot the dung was harder and drier.

Influence on the condition of the coat of the animals. The coat of the wet fed lot retained its condition throughout the period while the animals 
were receiving the wet food. After a change to the dry feeding the coat gradually got out of condition, the hair became dry and there was less gloss on it. With a change back to the wet feeding the coat regained its "bloom" again.

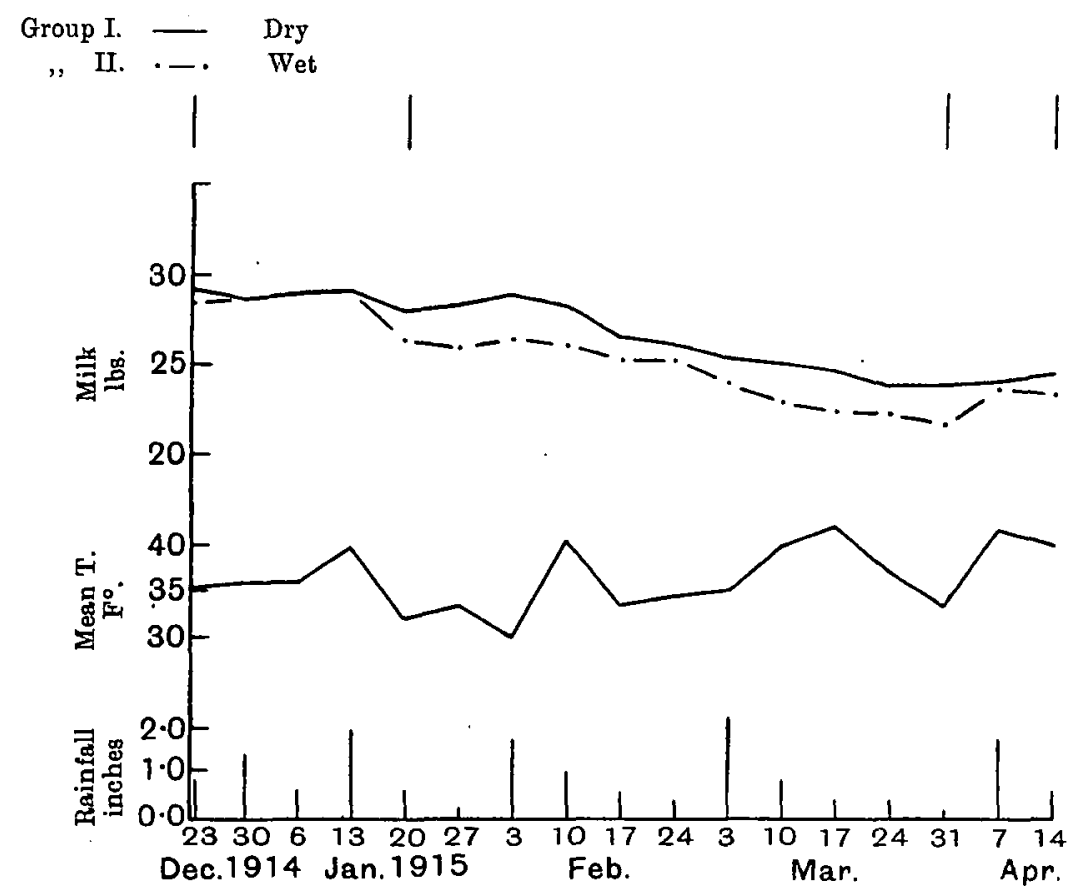

Fig. 2.

It was the opinion of Mr Young, who was in charge of this year's experiment, that the dry fed animals maintained their general health better than the wet fed lot. The feeding of sloppy food warm, if carried to extreme, deranges the digestive organs and renders the cows liable to chills ${ }^{1}$. But it can hardly be said that the feeding of warm sloppy food was carried to extreme in this case. However, continued looseness of the dung and a tendency to scour when spread over a long period, might eventually lower the condition of the animal and make it more susceptible to illness.

The warm water consumed daily in the sloppy meals amounted to one gallon. As the only difference between the two methods of feeding consisted in giving the concentrates warm and sloppy in one case and dry in the other it would appear that a difference in the amount of water

1 Cyclopedia of American Agriculture. Article on Cow-keeping, 1, 1907. Green \& Sons. 


\section{Wet and Dry Feeding of Concentrates to Dairy Cows}

consumed was probably the factor which affected the condition of the dung and of the coat of the animals.

Water supply. Drinking water was obtained from a trough in the yard, access to which was given along with the rest of the herd from 10 to $10.30 \mathrm{a} . \mathrm{m}$. each day. In cold weather some of the cows would return to the byre without going to the trough. Considering the great importance of water in the animal dietary, especially in the case of cows, who, in addition to the supplies necessary for the ordinary physiological functions which it has to perform in the body, require considerable amounts for milk production, and in view of these results, the possibility of the cows not always taking an adequate supply of drinking water, suggested itself. It was decided to put the point to a test.

A long narrow metal trough was placed at the back of the stalls, resting against the wall, below the rack, but high enough so as not to interfere with the cows eating from the trough let into the floor. The cows were given access to the water for about one half hour daily by lifting a lid which was afterwards closed for the rest of the day. The trough was divided by a partition, each half was graduated so that the total water consumed per day by the wet and dry fed animals respectively could be measured.

Drinking from the trough commenced in the second week in March and was continued until the end of the experiment.

Drinking water consumed. As would be expected the animals receiving the dry meal drank more water than the lot getting the wet meal. The total water consumed was as follows:

$\begin{array}{lcc} & \text { Gallons } & \begin{array}{c}\text { Average per cow per day } \\ \text { Gallons }\end{array} \\ \text { Dry fed lot } & 1275 & 5 \cdot 7 \\ \text { Wet " } & 1065 & 4 \cdot 6\end{array}$

The wet fed lot consumed an extra one gallon of water per day with the concentrates, but taking that into account the average total amount of drinking water consumed is slightly more for each of the dry fed animals. The latter animals also seemed keener for the water. Before the trough was put in, it was noticed that the wet fed animals took to the fodder better than the dry fed lot, although the amount of fodder taken daily was the same in each case.

Influence of liberal water supply. With accessibility to water made easier by the introduction of the trough into the byre, the differences in the appearance of the coat of the animals and in the texture of the dung which had previously characterised the result of the two methods of 
feeding the concentrates, became much less pronounced. In the case of the condition of the coat of the animal the difference practically disappeared, whilst the dung from the dry fed animal became softer. The advantage in the milk yield in favour of the wet meal over that of the dry meal was maintained, showing that the increased water supply although it improved the condition of the coat of the dry fed animals, it did not appear to influence the respective milk yields. The improvement in the coat was similar to that produced by feeding the wet meal following a period of feeding with the dry meal.

When examining the milk yield curves of individual animals, temporary increases were noticed. It was found that these corresponded with the week following date of service and it occurred in the case of four cows. Fleischmann ${ }^{1}$ states that the effect of bulling is to produce an immediate decrease in the yield of milk and fat, but almost directly afterwards the fat for a day or so is unusually high.

In the winter of 1915-16 some of the cows in the herd aborted, and owing to the war conditions then prevailing, there was a scarcity of, and a very limited selection of, foods available. In addition there was a great difficulty in procuring a suitable person to look after the experiment. As a result, further experimental work of this kind had to be postponed and it was not resumed again for several years.

\section{Water Consumption and Milk Production.}

It was decided to repeat the wet and dry feeding test under the same conditions as that of the latter part of the 1915 experiment when a liberal water supply was available. Arrangements were also made to measure the amount of drinking water consumed daily by each cow and to determine the amount contained in, and taken in, the food.

Except for the components of the ration the other details of the experiment were the same as in previous years. The water was given in buckets and each animal was allowed to drink as much as it wanted and the quantity measured. The cows were allowed out for exercise daily.

Daily ration for each cow.

\begin{tabular}{llrrr} 
& & & \multicolumn{2}{r}{ lbs. } \\
Swedes & $\ldots$ & $\ldots$ & $\ldots$ & 30 \\
Hay & $\ldots$ & $\ldots$ & $\ldots$ & 7 \\
Oat straw & $\ldots$ & $\ldots$ & 10 \\
Oats crushed & $\ldots$ & $\ldots$ & 3 \\
Fish meal & $\ldots$ & $\ldots$ & 1 \\
Miller's offal & $\ldots$ & $\ldots$ & 1 \\
Earth nut cake & $\ldots$ & $\ldots$ & 4
\end{tabular}

' Fleischmann, W. The Book of the Dairy. Blackie \& Sons, 1896, p. 40. 


\section{Wet and Dry Feeding of Concentrates to Dairy Cows}

This supplied in lbs.: dry matter, $27 \cdot 4$; digestible protein, $3 \cdot 3$; dig. carbohydrates and fibre, 12.3 and dig. oil, 0.6 .

Four animals calving within 17 days of each other were available. The feeding of the concentrates was as follows:

$$
\begin{aligned}
& 4 \text { weeks on the wet, } \\
& 7 \text { " } " \text { dry, } \\
& 4 \text { " wet. }
\end{aligned}
$$

The yield of milk in lbs., and the water consumed in gallons, also the mean weekly temperature and the rainfall are shcwn in Fig. 3 below. The mean temperature was less variable than that shown in Fig. 1, p. 82.

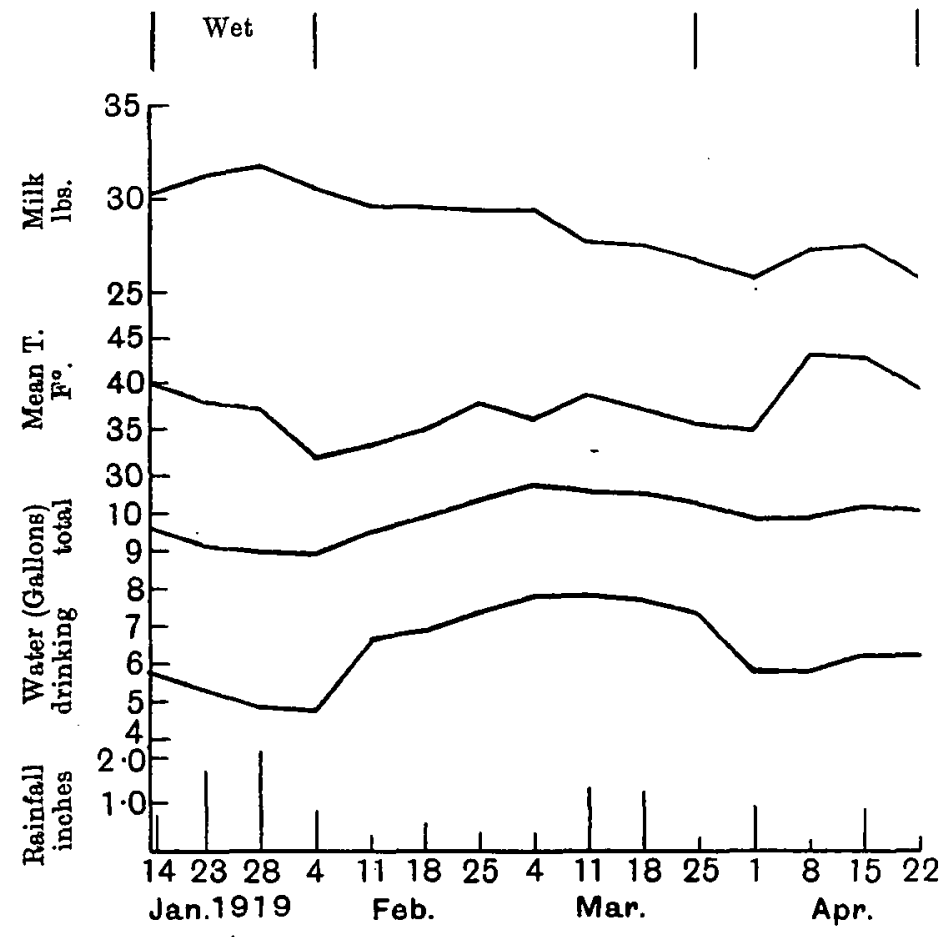

Fig. 3.

The result, in so far as the effect of the two methods of feeding on the milk yield was concerned, confirmed that for previous years. No difference however could be detected in the appearance of the coats of the animals as a result of feeding the food either wet or dry when a liberal water supply was available, but the dung from the animals receiving the wet meal was softer than that from the animals consuming the dry meal. 
The laxative effect produced by the wet meal can hardly be attributed to a difference in the amount of water consumed as the total quantity taken in the case of the dry fed animals was slightly higher than that consumed by the wet fed lot. The inference is that the laxative action is due to the consumption of the concentrated food in a warm sloppy state. Whatever may be the action on the efficiency of the digestive changes, it is plain that the feeding of the sloppy food, as indicated by the increased milk yield, reacts favourably upon the process of milk secretion. A fact which would indicate increased rather than a diminished absorption of nutritive material as a result of adding boiling water to the meal and feeding warm. A ration producing a slight laxative effect is considered to be an advantage to dairy cows.

Milk fat. The milk fat was determined in both the morning and evening milk of each cow in each of the experiments. When the results are represented graphically, the percentage of fat was shown to rise and fall in a general way, in the opposite direction to that of the milk yield.

Water requirements and milk production. The intake of water for $1 \mathrm{lb}$. of milk produced, also the total daily supply received by each cow is given in Table $I$.

\section{TABLE I.}

\begin{tabular}{|c|c|c|c|c|c|c|c|c|c|c|c|c|}
\hline \multirow[b]{2}{*}{$\begin{array}{l}\text { mber } \\
\text { of } \\
\text { imal }\end{array}$} & \multicolumn{3}{|c|}{ Wet Meals } & \multicolumn{3}{|c|}{ Dry Meal } & \multicolumn{3}{|c|}{ Wet Meal } & \multicolumn{3}{|c|}{ Average } \\
\hline & $\begin{array}{c}\text { Milk } \\
\text { yield } \\
\text { daily } \\
\text { lbs. }\end{array}$ & $\begin{array}{l}\text { Total } \\
\text { water } \\
\text { taken } \\
\text { daily } \\
\text { lbs. }\end{array}$ & $\begin{array}{l}\text { Total } \\
\text { water } \\
\text { to } \\
1 \text { lb. milk } \\
\text { produced }\end{array}$ & $\begin{array}{c}\text { Mills } \\
\text { yield } \\
\text { daily } \\
\text { lbs. }\end{array}$ & $\begin{array}{c}\text { Total } \\
\text { water } \\
\text { taken } \\
\text { daily } \\
\text { lbs. }\end{array}$ & $\begin{array}{c}\text { Total } \\
\text { water } \\
\text { to } \\
\text { l lb. milk } \\
\text { produced }\end{array}$ & $\begin{array}{c}\text { Millk } \\
\text { yield } \\
\text { daily } \\
\text { lbs. }\end{array}$ & $\begin{array}{c}\text { Total } \\
\text { water } \\
\text { taken } \\
\text { daily } \\
\text { lbs. }\end{array}$ & $\begin{array}{l}\text { Total } \\
\text { water } \\
\text { to } \\
1 \text { lb. milk } \\
\text { produced }\end{array}$ & $\begin{array}{c}\text { Milk } \\
\text { yield } \\
\text { daily } \\
\text { lbs. }\end{array}$ & $\begin{array}{c}\text { Total } \\
\text { water } \\
\text { taken } \\
\text { daily } \\
\text { lbs. }\end{array}$ & $\begin{array}{c}\text { Total } \\
\text { water } \\
\text { to } \\
\text { l lb. milk } \\
\text { produced }\end{array}$ \\
\hline 4 & $33 \cdot 1$ & $100 \cdot 9$ & $3 \cdot 0$ & $28 \cdot 6$ & $105 \cdot 8$ & $3 \cdot 7$ & $24 \cdot 1$ & $108 \cdot 4$ & $4 \cdot 5$ & $28 \cdot 6$ & $105 \cdot 0$ & $3 \cdot 7$ \\
\hline 19 & $29 \cdot 1$ & $85 \cdot 7$ & $2 \cdot 9$ & 27.0 & 99.9 & $3 \cdot 7$ & $26 \cdot 5$ & 92.7 & $3 \cdot 5$ & 27.5 & 92.8 & $3 \cdot 4$ \\
\hline 28 & 26.5 & 76.8 & 2.9 & $24 \cdot 5$ & $100 \cdot 4$ & $4 \cdot 1$ & 21.9 & $87 \cdot 6$ & $4 \cdot 0$ & $24 \cdot 3$ & 88.3 & $3 \cdot 7$ \\
\hline 35 & 35.8 & 103.8 & $2 \cdot 9$ & $34 \cdot 1$ & 112.5 & 3.3 & $33 \cdot 4$ & $110 \cdot 2$ & $3 \cdot 3$ & $34 \cdot 4$ & 108.8 & $3 \cdot 2$ \\
\hline rag & $31 \cdot 1$ & 91.8 & $2 \cdot 9$ & $28 \cdot 5$ & $104 \cdot 6$ & $3 \cdot 7$ & $26 \cdot 5$ & $99 \cdot 7$ & 3.8 & $28 \cdot 7$ & 98.7 & $3 \cdot 5$ \\
\hline
\end{tabular}

To produce $1 \mathrm{lb}$. of milk a cow requires, on an average, about $3.5 \mathrm{lbs}$. of water including drinking water and water contained in the food, when fed in the winter months on a ration containing $30 \mathrm{lbs}$. turnips, and part of the concentrates given as wet mashes. The ratio varied with individual cows. It increased as the milk yield diminished.

The feeding also affected the ratio as the total intake of water for the dry fed animal was greater than when the animal was fed on the wet 


\section{Wet and Dry Feeding of Concentrates to Dairy Cows}

meal. McCandlish and Gaessler ${ }^{1}$ found that $550 \mathrm{lbs}$. of water are required for 100 lbs. of milk produced in the summer.

The ratio would vary also according to the proportion of fodder in the ration. It is stated that for $1 \mathrm{lb}$. of dry matter taken in the food, $4 \mathrm{lbs}$. of water are consumed ${ }^{2}$. In the present experiment the ratio was $3.6 \mathrm{lbs}$. of water for $1 \mathrm{lb}$. of dry matter consumed.

As would be expected, the water requirements increased as the milk yield increased, and as the weather got warmer. The smaller animal, as it presents a relatively larger surface area for evaporation, consumed a relatively greater proportion of water than a larger animal.

The proportion of water contained in the milk to the total intake of water amounted in the present case on an average to about 26 per cent., and the remainder is made up of water secreted and lost by evaporation. About 62 per cent. of the total water taken was drinking water.

\section{TABLE IL.}

\begin{tabular}{|c|c|c|c|c|c|c|c|c|c|}
\hline \multirow{2}{*}{ Number } & \multirow[b]{2}{*}{$\begin{array}{l}\text { Weight } \\
\text { cwts. }\end{array}$} & \multicolumn{2}{|c|}{$\begin{array}{l}\text { Wet Meals } \\
\text { Percentage of } \\
\text { total water }\end{array}$} & \multicolumn{2}{|c|}{$\begin{array}{l}\text { Dry Meal } \\
\text { Percentage of } \\
\text { total water }\end{array}$} & \multicolumn{2}{|c|}{$\begin{array}{l}\text { Wet Meal } \\
\text { Percentage of } \\
\text { total water }\end{array}$} & \multicolumn{2}{|c|}{$\begin{array}{c}\text { Average } \\
\text { Percentage of } \\
\text { total water }\end{array}$} \\
\hline & & $\begin{array}{l}\text { drinking } \\
\text { water }\end{array}$ & in & $\begin{array}{c}\text { drinking } \\
\text { water }\end{array}$ & in & $\begin{array}{c}\text { drinking } \\
\text { water }\end{array}$ & in & $\begin{array}{l}\text { drinking } \\
\text { water }\end{array}$ & $\underset{\text { milk }}{\text { in }}$ \\
\hline 4 & 10.5 & $60 \cdot 1$ & 28.8 & $74 \cdot 6$ & $25 \cdot 0$ & $62 \cdot 8$ & $21 \cdot 1$ & 65.8 & $25 \cdot 0$ \\
\hline 19 & 12.0 & $53 \cdot 2$ & 32.3 & $69 \cdot 2$ & $24 \cdot 0$ & $56 \cdot 7$ & 23.2 & 59.7 & 26.5 \\
\hline 28 & $12 \cdot 25$ & $48 \cdot 1$ & $30 \cdot 2$ & $69 \cdot 8$ & $21 \cdot 6$ & $54 \cdot 3$ & $19 \cdot 2$ & $57 \cdot 4$ & 23.7 \\
\hline 35 & $10 \cdot 0$ & $61 \cdot 3$ & 30.5 & $73 \cdot 6$ & 26.8 & 63.7 & 29.3 & 66.2 & 28.9 \\
\hline \multicolumn{2}{|c|}{ Average } & $55 \cdot 7$ & 30.5 & 71.8 & $24 \cdot 4$ & $59 \cdot 4$ & 23.2 & $62 \cdot 3$ & $26 \cdot 0$ \\
\hline
\end{tabular}

The average percentage of water in the foods used in these experiments was:

\begin{tabular}{lcccr} 
& & & & $\%$ \\
Bean meal & $\ldots$ & $\ldots$ & $\ldots$ & $14 \cdot 1$ \\
Crushed oats & $\ldots$ & $\ldots$ & $13 \cdot 5$ \\
Paisley meal... & $\ldots$ & $\ldots$ & $15 \cdot 0$ \\
Miller's offal & $\ldots$ & $\ldots$ & $13 \cdot 2$ \\
\multicolumn{2}{l}{ Decorticated cotton cake } & $\ldots$ & $9 \cdot 6$ \\
Earth nut cake & $\ldots$ & $\ldots$ & $10 \cdot 1$ \\
Bran ... & $\ldots$ & $\ldots$ & $\ldots$ & $13 \cdot 5$ \\
Fish meal & $\ldots$ & $\ldots$ & $\ldots$ & $13 \cdot 0$ \\
Hay $\ldots$ & $\ldots$ & $\ldots$ & $\ldots$ & $14 \cdot 1$ \\
Oat straw & $\ldots$ & $\ldots$ & $\ldots$ & $14 \cdot 0$ \\
Swedes & $\ldots$ & $\ldots$ & $\ldots$ & $90 \cdot 0$
\end{tabular}

1 McCandlish, A. C. and Gaessler, W. G. "Water requirements for millk production." Journ. of Dairy Science, 2, No. 1, 1919, 8.

$\cdot 2$ Cyclopedia of American Agriculture, 3, 1908. 
It was a practice in some of the milk selling farms in the west of Scotland to feed beavy root rations amounting to a hundredweight of roots per day. Dunstan ${ }^{1}$ states that over $100 \mathrm{lbs}$. of roots are fed per head per day on some of the farms in Kent. A presumption is that drinking water is essential for dairy cows even when fed on a succulent diet $^{2}$. Lauder and Fagan ${ }^{3}$ found that cows receiving 112 lbs. of roots per head per day with wet mashes refused drinking water. In this experiment the total water consumed for moderate milking cows in winter amounted to about 10 gallons per day (Table I, p. 89). This quantity would be supplied by one hundredweight of roots.

\section{Drinking Water and Water supplied in Succulent Foods.}

The effect of supplying the water requirements in the form of succulent food compared with a ration in which part of the water was taken as drinking water was tried.

Plan of experiment. In the first period the cows were given $112 \mathrm{lbs}$. of roots daily along with fodder and concentrates. In the second period the allowance of roots was reduced by one half while the fodder and the concentrates were adjusted so as to supply the same weight of proteins, fats and carbohydrates. The last period was the same as the first. The introduction of the heavy root ration was spread over about ten days. Eight cows calving within 51 days of each other were available.

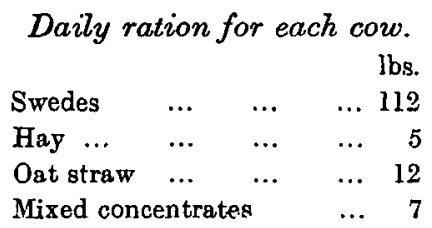

The mixed concentrates were made up in the following proportion: $2 \mathrm{lbs}$. each of bean meal, earth nut cake, oat hash, bran and $1 \mathrm{lb}$. fish meal. One half was fed dry and the remainder in a sloppy condition.

The ration supplied in lbs. : dry matter, 28.3 ; dig. protein, $2 \cdot 8$; dig. oil, 0.37 ; dig. carbohydrates and fibre, $15 \cdot 2$.

The yield of milk in lbs., the percentages of fat, and of solids-not-fat are shown in Fig. 4, p. 92, along with the consumption of water in gallons and the weather conditions.

1 Dunstan, W. R. "Cost of feeding in milk production." Trans. H. and Ag. Soc. of Scot. Fifth series, 23, 1911, 147.

2 MoCandlish and Gaessler, ibid.

S Lauder, A. and Fagan, T. M. "The effect of heavy root feeding on the composition and yield of milk." Bull. 26. Edin. and E. of Scot. Ag. Coll., 1912. 


\section{Wet and Dry Feeding of Concentrates to Dairy Cows}

The effect of the heavy root feeding was to convert a distinct tendency on the part of the milk yield to increase into a definite decrease which persisted for two weeks after the heavy root feeding had given place to one half the allowance of roots. The milk yield of the cows in the several weeks preceding the commencement of the heavy root feeding is not shown in the graph.

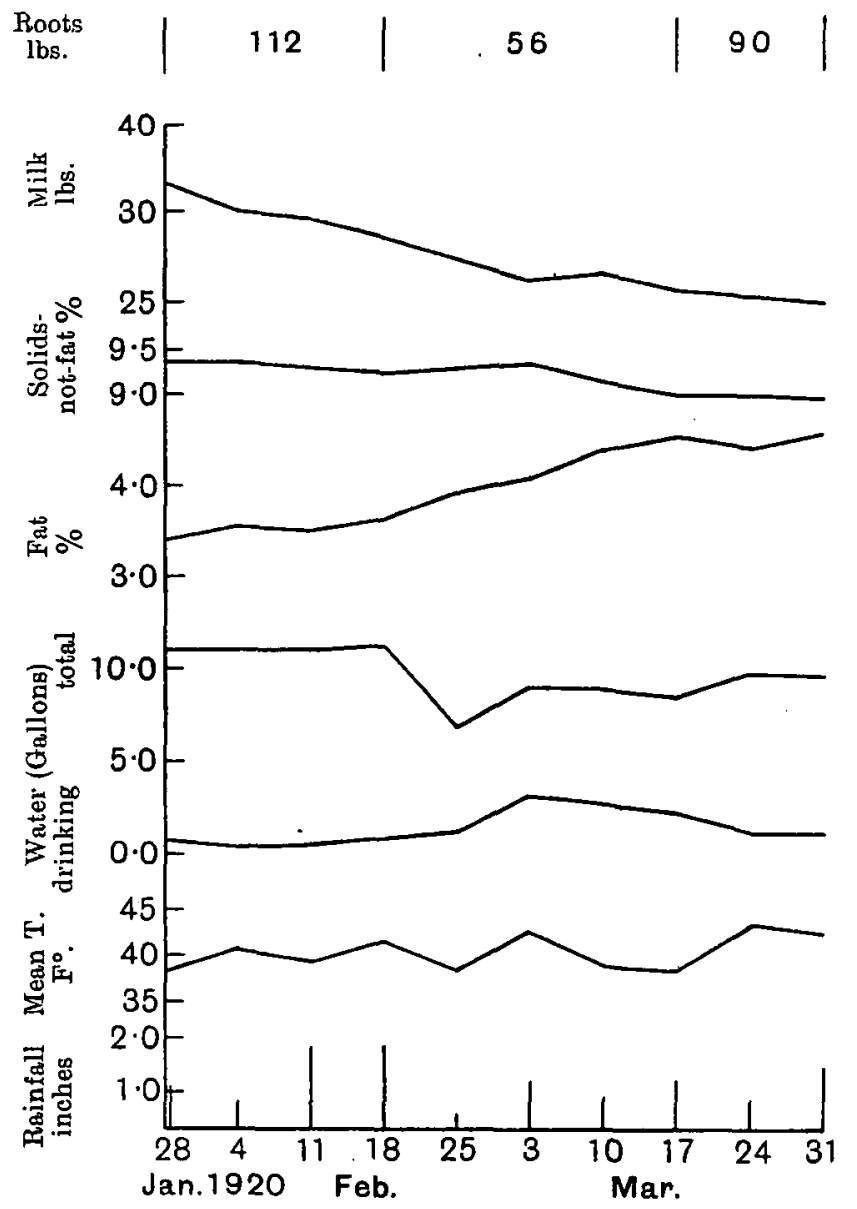

Fig. 4.

The percentage of fat showed a small but continuous increase. The increase was more rapid after the change from the heavy root ration. It was greater than could be accounted for by a shrinkage in the milk yield, see Table III, p. 93, although the change of feeding did not alter the supply of nutritive material as calculated by the usual method. 
The percentage of solids-not-fat remained almost stationary although there was a fall in the milk yield. The actual weight diminished, but more rapidly under the heavy compared with the moderate root ration, see Table III below.

The proportions of proteins and of solids-not-fat are found to increase as the lactation advances ${ }^{1}$. On the other hand Crowther ${ }^{2}$ finds that the percentage of sugar and solids-not-fat decreased while the proteins increased as the lactation advances.

\section{TABLE III.}

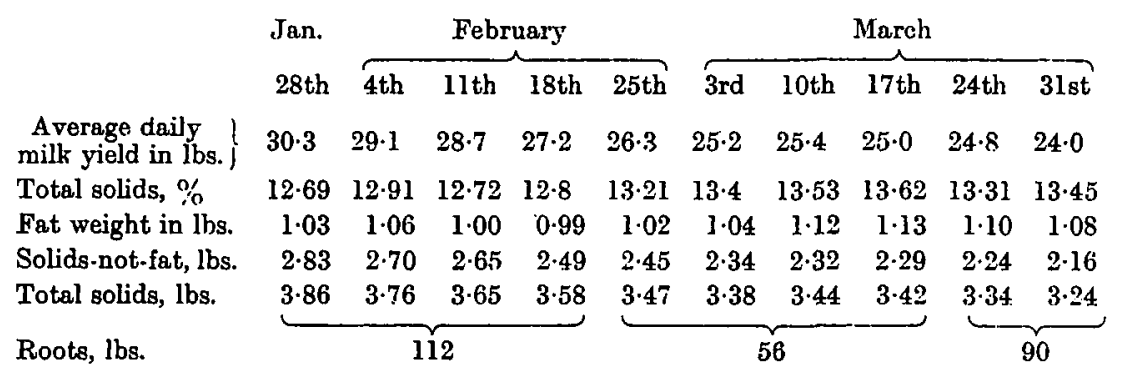

Four out of the seven cows in the experiment took drinking water regularly while on the high root ration and the average quantity taken amounted to 5.1 per cent. of the total intake of water. The water supplied in the roots sufficed for the requirements of the remainder of the cows. The average total water per cow taken daily while on the beavy root ration was $110 \mathrm{lbs}$., ccmpared with $82 \mathrm{lbs}$., of which 28 per cent. (see Table IV, p. 94) was drinking water when the cows were fed on a moderate root ration. On the high root ration the proportion of total water to $1 \mathrm{lt}$. of milk produced was $3.9 \mathrm{lbs}$. and $3.3 \mathrm{lbs}$. on the moderate root ration. Table IV, p. 94.

The cows scoured badly while on the heavy root diet and the byreman complained that their health was being adversely affected. The scouring did not cease until some time after the change of feeding to the moderate root ration. The scouring in this case is the result of feeding excessive quantities of succulent food. The temperature of the water (about 100 lbs.) in the roots would often not be many degrees above that of freezing point in the winter months.

1 Van Slyke, I. I. and Publow, C. A. Science and practice of cheese-making. Orange Judd \& Co. New York, 1914, 162. Berry, R. A. "Yield aind composition of cow's milk during lactation." Bull. 76. W. of Scot. Ag. Coll. Glasgow, 1916.

s Crowther, Charles. "Variation in the composition of cow's milk with advance in lactation." Trans. B. and Ag. Soc. of Scot., 1911, 22. 
94 Wet and Dry Feeding of Concentrates to Dairy Cows

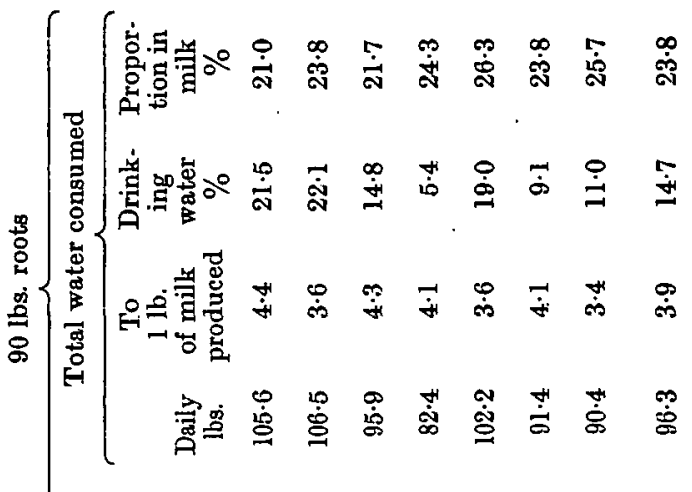

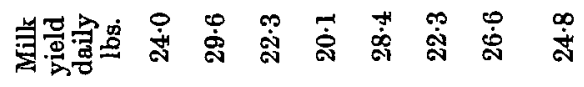

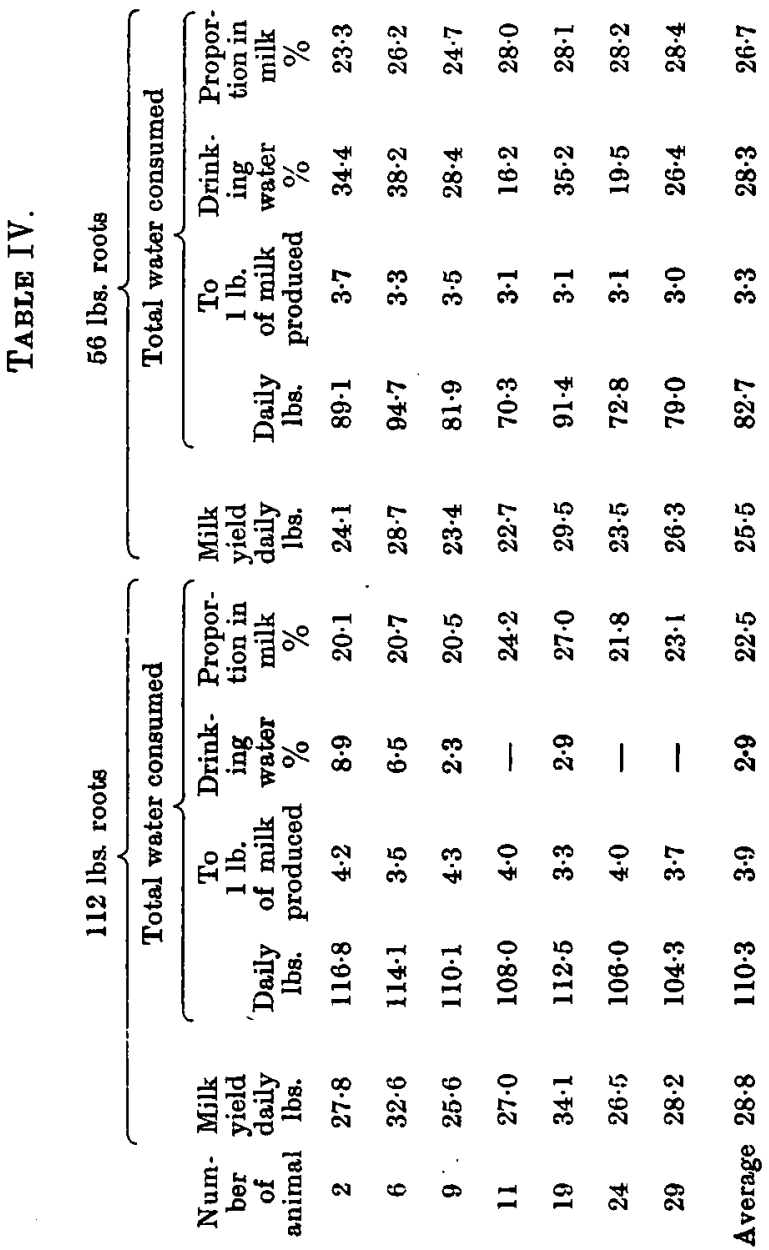


The turning out of the cows to pasture in the spring and sometimes when a change is made from ordinary pasture to aftermath, also produces a pronounced laxative effect, but the milk yield invariably shows a marked increase covering a few weeks and accompanied by a perceptible fall in the percentage of milk fat.

A cow on pasturage is generally supposed to eat about a hundredweight of grass a day. An average sample of grass would supply in lbs.: dry matter, 25; dig. crude proteins, $3 \cdot 8$; dig. carbohydrates and fibre, 12.2; dig. oil, 0.37. Except for the crude proteins there is less nutritive substances than supplied by the heavy root ration used in the foregoing experiment. In the latter case there was a fall in the milk yield and a rise in the fat and the reverse in the former case.

Temperature and Milk Secretion.

In an earlier part of this paper (p. 83) it was remarked that a change of temperature might be one of the contributory causes which accounts for the irregular form of the daily milk yield curves. The mean temperature inside the byre in the winter months is, as a rule, from $15^{\circ}$ to $20^{\circ}$

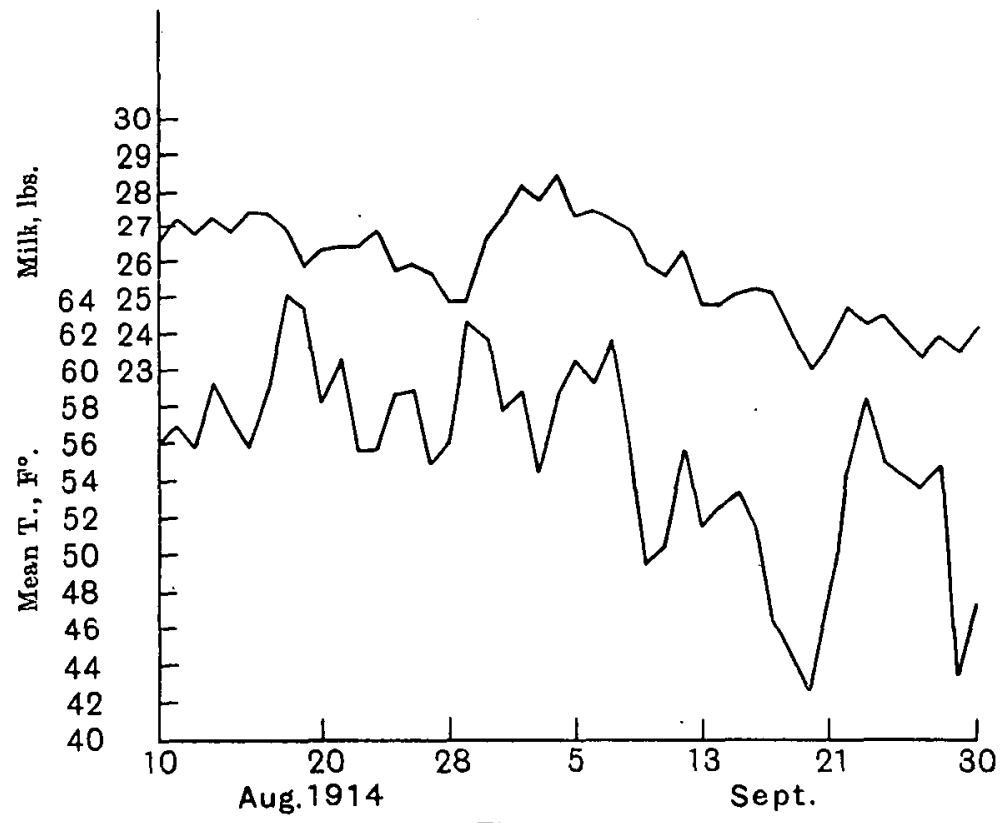

Fig. 5.

higher than that of the outside air and it is subject to much less variation. A curve has therefore been drawn up to show the daily mean 


\section{Wet and Dry Feeding of Concentrates to Dairy Cows}

temperature of the outside air and the average daily yield of milk of cows out all night on pasture in the early autumn. See Fig. 5, p. 95.

From an inspection of the graph for the month of September there appears to be a connection between the curve showing the variation of the milk yield and the curve for the mean temperature. The possibility of this being accidental must be kept in sight in view of the fact that in this month the mean daily temperature tends to fall and the milk yield as a result of advancing lactation diminishes. The rainfall is not included in the graph, but animals at this time of the year, resting over-night on pastures sodden after rain, would almost certainly intensify any effect produced by a falling air temperature.

A similar curve for the winter months giving the mean daily temperature in the byre and in the outside air, and the daily milk yield is shown below (Fig. 6).

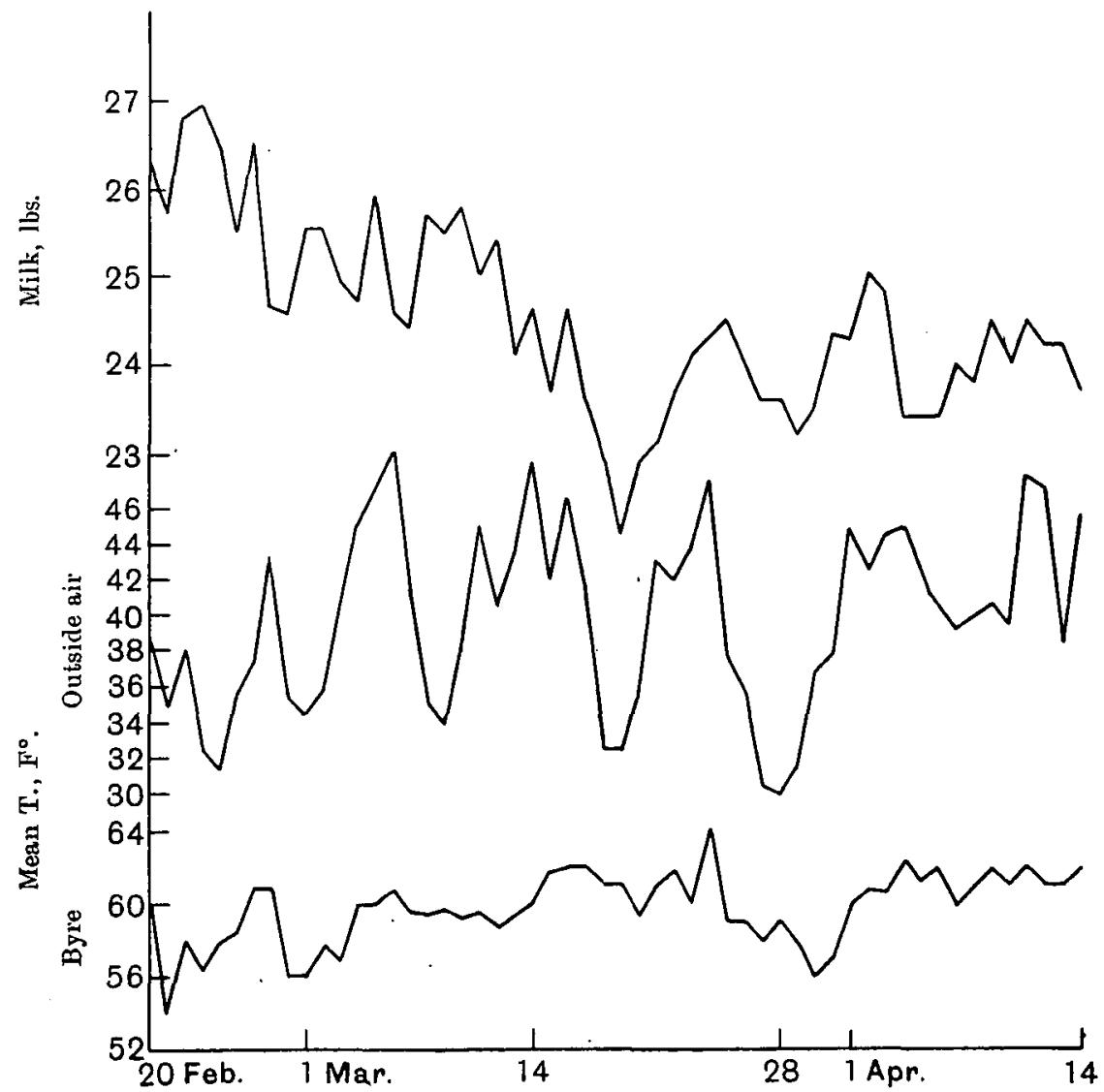

Fig. 6. Byre readings were taken at 9 a.m. and 5 p.m. and the two figures averaged. 
In the latter half of the curve there again appears to be a connection between a pronounced change of temperature and milk secretion. A comparison of the milk figures for a period of a comparatively low following or preceding that of a comparatively high temperature, shows that a lowering of the temperature depresses the yield while an increase in the temperature improves the yield. In other cases which were plotted out there seemed to be no connection between the two. Obviously there are other factors concerned, and further data are being obtained.

In an experiment carried out by the Highland and Agricultural Society of Scotland in $1908^{1}$ it was found that the milk yield from cows housed in a byre kept well ventilated and cool was slightly higher compared with that of cows housed in an adjacent byre which was badly ventilated, but warmer. The average temperature of the former was $49.8^{\circ} \mathrm{F}$. and for the latter $59.4^{\circ} \mathrm{F}$. The purity of the air would not be the same in the two cases.

The effect on the milk fat of a marked fall in temperature has been found to produce a fat with a lower butyric acid content as indicated by the Reichert-Mejsel number ${ }^{2}$. The effect on the yield of fat was indefinite. Figs. 1, 2 and 3 should be examined in the light of the foregoing observations.

\section{SUMmaRY.}

The feeding of concentrates after scalding with boiling water and given to cows in winter in a sloppy condition at body temperature, increased the yield of milk by about $1 \mathrm{lb}$. per head per day over the yield produced when the concentrates were fed in a dry state. The increase diminished with the advance in lactation.

The warm mashes produced a distinct laxative effect.

The animals took to the wet mashes better than to the dry meals.

When the concentrates were fed as dry meals in a ration containing $30 \mathrm{lbs}$. roots with fodder and the drinking water taken from a trougb in the yard, the coat of the animals got out of condition. With a change to the wet meal or when the drinking water was accessible in the byre, the coat regained its condition again.

An improved water supply did not appear to affect the milk yield. The percentage of milk fat increased as the milk yield decreased.

1 Speir, John. "Influence of temperature on milk yield." Trans. H. and Ag. Soc. of Scotland. Fifth series, 21, 1909, 255-306.

"Berry, R. A. "Yield and comp. of cow's milk during lactation." Bull. 76, W of Scot. Ag. Coll. Glasgow, 1916, 49-73.

Journ. of Agric. Sci. xI 


\section{Wet and Dry Feeding of Concentrates to Dairy Cows}

Dairy equipment includes a boiler, therefore little, if any, additional capital outlay should be necessary for scalding the meals.

On an average $3.5 \mathrm{lbs}$. of water were assimilated to $1 \mathrm{lb}$. of milk produced in a normal winter ration (see p. 89 ). The ratio varied with the feeding, the temperature and the period of lactation.

Drinking water and water consumed in the food amounted to about ten gallons daily, and of this between 50 and 60 per cent. was drinking water. The amount increased with an increase in the yield of milk and with a rise in the temperature. The smaller cows also consumed a relatively larger proportion of drinking water. From 25 to 30 per cent. of the total intake of water was contained in the milk.

The feeding of a large weight of roots (112 lbs.) with meals and fodder caused the animals to scour badly. The health and the condition of the animal were also adversely affected. The milk yield which had shown a tendency to increase was converted into a definite decrease. There was an increase in the percentage of fat, although the total weight produced diminished. The fall in the milk yield was partly though not immediately arrested by a change to a moderate root ration and there was a decided increase in the percentage of, and in the total yield of, fat. Heavy root feeding would therefore appear to depress fat formation, though the supply of nutritive material in the food as judged by the usual method of calculation was not diminished.

The total weight of water consumed for $1 \mathrm{lb}$. of dry matter in the food amounted to $3.9 \mathrm{lbs}$. with the heavy and $3.3 \mathrm{lbs}$. with the moderate root ration. Some of the cows took water daily amounting on an average to between 5 and 6 per cent. of the total intake of water while on the heavy root ration.

Preliminary data relating to temperature and milk secretion were given.

Ayrshire cows were employed in the experiments.

The late Lieutenant H. A. Wyllie, B.Sc. was in charge of the 1913-14 experiment and Mr Hugh M. Young of the 1914-15 experiment. Determinations of the percentage of total solids in the milk were made by Mr Peter Caldwell.

Any additional expenditure incurred in carrying out these experiments was defrayed by the Board of Agriculture for Scotland. 